Barbara Lampič

\title{
Irena Mrak: \\ High Mountain Areas and Their Resilience to Tourism Development / Visokogorska območja in nihovo odzivanje na razvoj turizma
}

Ljubljana: Znanstvena založba Filozofske fakultete Univerze v Ljubljani, 2011, 168 strani

Raziskave na področju geografije gora so v Sloveniji zaenkrat maloštevilne, knjiga dr. Irene Mrak, raziskovalke na Oddelku za geografijo Filozofske fakultete Univerze v Ljubljani, pa v geografski stroki prav zato predstavlja pomembno novost. Sorodne vsebine se v tujini že vrsto let uveljavljajo v znanstvenih sferah številnih strok. Poudariti velja predvsem dejstvo, da monografija ne le v teoretično-metodološkem, ampak tudi empiričnem delu presega slovenske razmere; predvsem s sistematično predstavitvijo rezultatov večletnega empiričnega dela in obiskov številnih svetovnih gorstev.

Knjiga je izšla v okviru zbirke GeograFF na Oddelku za geografijo Filozofske fakultete Univerze v Ljubljani in je prvo tovrstno delo s področja geografske stroke, ki se ambiciozno in hkrati dovolj sistematično loteva naraščajočega problema sodobnega razvoja turizma $\mathrm{v}$ visokogorju po svetu $\mathrm{z}$ upoštevanjem specifičnih naravnih in socioekonomskih razmer.

Avtorica si v svojem delu zastavlja dva kompleksna cilja, ki ju podrobno predstavi in izpostavi že v uvodnih poglavjih. Na metodološkem polju je osnovni cilj »... razviti univerzalni model sonaravnega razvoja turizma in rekreacije $\mathrm{v}$ visokogorju, ki upošteva tako vrednotenje (različnih) naravnogeografskih razmer kot aktualne antropogene pritiske ...«. Kompleksnost modela, ki ga avtorica sočasno razvija in v nadaljevanju tudi empirično preizkusi na primeru visokogorja v Pakistanu, dopolnjuje še povsem nov vidik zaznavanja ekoloških problemov (različnih nosilcev dejavnosti na različnih visokogorskih območjih). Model zaključuje in mu daje dodatno uporabno vrednost še nabor možnih ukrepov, ki zmanjšujejo pritiske dejavnosti (turizma) na gorskih območjih. Drugi cilj je empirične narave; avtorica je model uspešno preizkusila na primeru vzorčnega območja regije Baltistan (ledenika Baltoro v Pakistanu). 
Delo je kljub obsežnosti tematike strnjeno predstavljeno na 168 straneh, obogateno pa je s tematskimi kartami, preglednicami, grafičnimi ponazoritvami in $\mathrm{z}$ izvrstnim fotografskim gradivom. Prav povednost fotografij, ki jih je v celoti prispevala avtorica sama, dodatno prispeva $\mathrm{k}$ razumevanju tematike in tudi nepoznavalcem približa vsebino. Uvodna poglavja so teoretično-metodološke narave, posebno poglavje $s$ pregledom razvoja turizma in rekreacije $\mathrm{v}$ visokogorju po svetu pa je zanimivo tako za strokovno kot laično javnost.

Delo je razdeljeno na 6 vsebinskih poglavij, pri čemer so prva štiri namenjena teoretičnim izhodiščem, pregledu razvoja turizma in rekreacije na visokogorskih območjih po vsem svetu, oblikam turizma na teh območjih ter pregledu okoljskih, socialnih in ekonomskih vplivov turizma. Osrednji del knjige je namenjen konceptu načrtovanja sonaravnega razvoja turizma in rekreacije ter razvoju lastnega modela načrtovanja in doseganja sonaravnega razvoja turizma $\mathrm{v}$ visokogorju. Ta je bil preizkušen na primeru Baltistana $v$ Pakistanu, ki ga avtorica proučuje zadnje desetletje. $\mathrm{V}$ zaključkih je velik poudarek namenjen še ugotavljanju dejanskega pomena zavarovanih območij $\mathrm{v}$ visokogorju ter predvsem ukrepom, ki bodo dolgoročno prinesli spremembe tako pri odzivanju gorskih območij na povečan pritisk turizma kot tudi pri vedenjskih vzorcih obiskovalcev.

Razvijanje inovativnega modela sonaravnega razvoja turizma v visokogorju temelji na metodoloških izhodiščih ranljivosti okolja, prilagojenih specifiki problematike. Tudi izbor in ovrednotenje izbranih kriterijev je ustrezno prilagojen. Pri obravnavi antropogenih vplivov je avtorica uporabila model DPSIR (oziroma njegova izhodišča). Poleg tega avtorica korektno uporabi tudi številne druge preprostejše statistične metode, ki so za takšne analize običajne in primerne. Poudariti velja še vrednost intervjujev, ki so bili izvedeni z najpomembnejšimi akterji na področju turizma proučevane regije.

Nabor uporabljenih bibliografskih referenc je obsežen in vsebinsko heterogen. Prevladujejo tuji viri, kar je posledica dosedanje odsotnosti del s področja pričujočega znanstvenega dela pri nas. To dodatno kaže na potrebo po objavi/-ah s tematskega področja dela, ki so bile $\mathrm{v}$ slovenskem znanstvenem prostoru do sedaj očitno zapostavljene.

Besedilo je kljub specifični terminologiji ter obsežnemu znanstvenemu aparatu pregledno in berljivo tudi za tiste, ki niso povsem vešči koncepta izražanja in razmišljanja geografskih in okoljskih ved. Zasluge za to gre pripisati dobri organizaciji besedila ter bogati dodatni tabelarični in slikovni opremljenosti, ki vsebinsko in vizualno pomembno dopolnjuje novo vsebino, obenem pa povečuje privlačnost in razumljivost in nenazadnje uporabnost znanstvenega dela. Tu velja izpostaviti še terminološko jasnost, ki je v številnih primerih inovativna. 
Poleg inovativne vsebine pa se je avtorica spopadla še z eno prepreko - jezikom in prilagoditvijo terminologije. Delo je namreč v celoti napisano v angleškem jeziku (razen obsežnega povzetka $\mathrm{v}$ slovenskem jeziku), kar mu daje posebno mednarodno težo in večjo uporabnost, gotovo pa tudi večjo odmevnost. 